\title{
AS CONTRIBUIÇÕES À FILOSOFIA EM UMA VISÃO PRÉVIA
}

uma meditação histórica sobre a vigência do ser

\author{
CONTRIBUTIONS TO PHILOSOPHY IN A PREVIOUS VIEW \\ a historical meditation about the validity of being
}

\author{
Rodrigo Amorim Castelo Branco ${ }^{1}$ \\ (rodrigocasbr@hotmail.com)
}

\begin{abstract}
RESUMO
A partir da visão prévia (Vorsicht) das Contribuições à filosofia, a proposta do artigo é discutir sobre o acontecimento apropriador (Ereignis) como a essência do pensamento de Heidegger que abre a filosofia do Ocidente ao pensar do outro princípio (acolhedor do ser (Seyn) em seu profundo velamento) distinto do saber do primeiro princípio (o saber metafísico, que durante séculos identificou o ser com o ente em suas representações). Nesse sentido, demonstramos, a partir das considerações de Heidegger, como o pensar do outro princípio se torna uma meditação histórica que permite o advento do questionamento espantoso, mas, ao mesmo tempo, possibilita o perguntar sereno sobre a essência da verdade acerca do acontecimento apropriador. Fica claro que o espanto se dá no ser-aí porque ele compreende que a sua situação finita no mundo acontece pela retração do ser. Contudo, daqui surge a serenidade, porque o seraí percebe que o ir embora do fundamento é o que lhe permite existir como possibilidade no mundo.
\end{abstract}

Palavras-chave: Ser. Ser-aí. Acontecimento apropriador. Técnica. Maquinação.

\begin{abstract}
From the previous view (Vorsicht) of Contributions to Philosophy, the proposal of this article is to discuss the event of appropriation (Ereignis) as the essence of Heidegger's thought, which opens up the philosophy of the West to the thought of the other principle (welcoming of being (Seyn) in its deep concealment) distinct from the knowledge of the first principle (the metaphysical knowledge that for centuries identified the being with the entity in its representations). In this sense, we demonstrate, from Heidegger's considerations, how the thinking of the other principle becomes a historical meditation that allows the advent of the astonishing questioning, but at the same time makes possible the serene question about the essence of the truth about the event of appropriation. It gets clear that the astonishment happens in the being-there because it comprehends that its own finite situation in the world happens because of the withdrawal of being. However, hence comes serenity, because being-there perceives that to leave the foundation behind is what will allow it to exist as a possibility in the world.
\end{abstract}

Keywords: Being. Being-there. Event of appropriation. Technique. Machination.

\footnotetext{
${ }^{1}$ Doutorando em Filosofia pela Universidade de Brasília (UnB).

CV Lattes: http://lattes.cnpq.br/5921458335361133.

ORCID: https://orcid.org/0000-0003-0309-0059.
} 


\section{INTRODUÇÃO}

A nossa predileção pela questão da meditação histórica acerca da vigência do ser $(\operatorname{Seyn})^{2}$ nas Contribuições à filosofia (Do acontecimento apropriador) (Beiträge zur Philosophie (Vom Ereignis), 1936-38, GA 65) ${ }^{3}$ acontece pelo fato de se tratar de um tema novo ao leitor brasileiro e ainda pouco estudado no meio acadêmico. Além disso, a obra se apresenta como um contraponto significativo à perspectiva ôntica da tradição metafísica que esteve fixa na dimensão da entidade do ente por mais que tenha buscado alcançar o sentido do ser enquanto ser. A linguagem e o itinerário heideggerianos da obra aqui referida chamam a atenção para um modo de pensar a fundação e a história do homem em sua temporalidade por vias distintas das que foram propostas pela metafísica no pensamento ocidental. As Contribuições à filosofia parecem incitar um silêncio pensante que ainda não foi acolhido pela contemporaneidade técnica e calculante. Portanto, tendo-se em vista a emergência do advento de um pensamento que possa iluminar a história humana sobre o seu real fundamento e condição existencial, a meditação sobre o Ereignis é o que escolhemos estudar continuamente.

Este texto tem como meta trazer à luz as considerações preambulares do pensamento

das Contribuições à filosofia que Heidegger intitula visão prévia (Vorsicht). Assim, delimitamos a nossa discussão, tomando como fio condutor elucidar o elemento nuclear do pensamento heideggeriano nessa sua fase de maturidade filosófica: a vigência do ser (Seyn) como acontecimento apropriador na história do Ocidente, que funda homens e épocas.

A Vorsicht é o momento das Contribuições à filosofia que, mesmo tendo caráter introdutório, não se reduz a mero resumo. Contrariamente, ela é uma visão antecedente e preparatória para a complexidade que advém nas páginas posteriores. Ao mesmo tempo, a Vorsicht já é o ingresso no profundo e enigmático pensamento acerca da história do ser (Seynsgeschichte) em seu vigor apropriante. Tal mirada talvez possa ser compreendida como

\footnotetext{
${ }^{2}$ Seyn é o termo que Heidegger utiliza nas Beiträge zur Philosophie para demonstrar que o ser (Seyn) do qual ele trata não é o ser (Sein) da ontologia tradicional, que durante séculos, no Ocidente, foi identificado com o ente. Seyn é o ser da virada (Kehre) do pensamento ocidental, indicando o acontecimento apropriador (Ereignis) como o fundamento nulo que se apropria do ser-aí e o funda a cada vez. Seyn é traduzido para o português arcaico "seer" na obra Contribuições à filosofia (Do acontecimento apropriador) por Marcos Antônio Casanova, lançado pela editora Via Verita no ano de 2015. Neste artigo, optamos por manter o termo ser, contudo, sempre orientando o leitor de que estamos nos referindo ao ser (Seyn) em sua distinção abissal e fundacional para com a concretude finita do ente. Nas citações, mantivemos a grafia "seer".

${ }^{3}$ As obras de Heidegger, no seu todo, estão dispostas (organizadas) em quatro seções dividas da seguinte forma: I. Escritos publicados; II. Conferências; III. Material não publicado, palestras e notas; IV. Notas e registros. Cada obra é identificada por um número na extensa edição completa (Gesamtausgabe) de Heidegger, cuja sigla é GA.
} 
um reforço propedêutico e hermenêutico de pensamento que possibilita ao leitor se debruçar e alcançar a luz da obra, "visualizando" o que as suas junturas (Fügungen) ${ }^{4}$ têm a dizer em seus momentos subsequentes. As Contribuições à filosofia, em sua totalidade, retomam as condições iniciais de exposição em uma perspectiva de desdobramento da visão prévia durante toda a estruturação do texto, evidenciando uma leitura árdua, mas aprazível quando os sentidos do livro começam a germinar.

O que a Vorsicht anuncia preliminarmente? Em seções, ela apresenta o pensamento nuclear das Contribuições à filosofia. A pergunta fundamental (Grundfrage) é delineada: “como o ser (Seyn) se essencia ou vige?” Uma resposta prévia, que será insistentemente debatida nos desdobramentos da obra é apresentada: o ser vige "como a ressonância da recusa" (HEIDEGGER, 2015, p. 13). Esse excerto será melhor compreendido no decorrer deste artigo, em suas três seções, nas quais buscamos compreender o modo de doação do ser em seu caráter de retração.

A partir da visão prévia das Contribuições à filosofia, o que nos move é o intuito de indicar o estilo do pensamento fenomenológico de Heidegger a partir de sua obra tardia. Buscase traçar um roteiro de escrita que demonstre o seu pensamento expresso em uma linguagem estranha e incomum ao que a tradição ontológica está acostumada. O estilo filosófico de Heidegger não se respalda na dimensão do ente, mas é acolhedor do acontecimento apropriador como o Nada fundante (Seyn). Trata-se de um estilo radical, porque retém os acenos do ser em sua nadificação, isto é, em sua recusa essencial.

Na primeira seção deste artigo o intento é demonstrar como a filosofia do outro princípio (meditação sobre o sentido originário da verdade), bem como o pensamento do primeiro princípio (metafísica) são, fundamentalmente, fundações não do ser-aí (Dasein), mas do acontecimento apropriador sobre o ser-aí, demonstrando o caráter essencial desse evento.

A abertura do ser advém como velamento, ela escapa ao poder do ente, ela passa ao largo de suas representações. O cálculo e a técnica se demonstram aptas tão só a mobilizar o ente enquanto ente, mas não o ser em sua simplicidade. Ao se ocultar, a senda originária se esvai, retrai-se à vontade de potência dos juízos das vivências (Erlebnisse). Essa é a abertura nadificadora do acontecimento apropriador, que faz ver um modo de niilismo em Heidegger, mas não no sentido de perda de significado ou de vácuo de possibilidades. Niilismo aqui aponta

\footnotetext{
${ }^{4}$ Seções estruturantes, juntas ou os encaixes que compõem as Contribuições à filosofia. A obra delineia as seis junturas (Fügungen) que indicam os "caminhos" pelos quais o ser se re-vela: a ressonância (der Anklang), o passe (das Zuspiel), o salto (der Sprung), a fundação (die Gründung), Os que estão por vir (Die Zu-künftigen) O último deus (Der letzte Gott) e a seção O seer (das Seyn).
} 
para o nada significante que traça os caminhos da história ao seu modo ao apropriar o ser-aí, indicando a ele possibilidades de ser no mundo.

O ser-aí, quando se distancia da essência que o funda, toma para si os próprios rumos de sua existência, não compreendendo que um princípio fundante e anterior à existência de qualquer ente habita o nada, é o nada e a partir do nada apropria tudo que há. Negar a essência nadificadora do ser significa distanciar-se de um acontecimento primordial e singelo sem o qual o homem não poderia ser essenciado e fundado no mundo como projeto sempre em lançamento. Esta distância, que coloca o homem na dimensão da inautenticidade, é o que fortalece a coisificação da vida, porque passa a imperar a técnica, o que Heidegger chama de maquinação (Machenschaft), dimensão do império da plena factibilidade sobre a terra, o ar, o fogo, a água e sobre todos os demais elementos que estão à disposição do cálculo humano.

Na segunda seção deste artigo, discutimos sobre a pergunta espantosa e serena acerca do sentido do ser (Seyn). Trata-se de um questionamento espantoso, porque no outro princípio do pensamento (acolhimento do ser em sua total diferença ontológica para com o ente) percebese que essa essência é um abismo, um vazio nadificador. Mas a pergunta é serena, porque se sabe que tal essência é um vazio que fala aos seus próprios modos e que abre o tempo-espaço do ser-aí e, a partir disso, funda a história.

$\mathrm{Na}$ última seção, buscamos compreender como Heidegger, em outra via, distinta da maquinação, apresenta-se como um pensador que medita sobre a história e não como aquele que faz considerações historiológicas. A meditação histórica acolhe o advir essencial do ser, o seu retraimento como uma vigência primordial que funda a história, mas que não pode ser calculada ou domada pelo intelecto. Diferentemente do campo historiológico, que visa conhecer, predicar, criar um método de fundamentação teórica que represente o seu objeto de estudo, as meditações de Heidegger pensam a livre doação do ser sem qualquer subordinação a outra natureza que não seja a sua própria liberdade de vir à tona.

Por fim, as três seções deste artigo estão entrelaçadas assim como estão a visão prévia (Vorsicht) e as próprias Contribuições à filosofia. No texto heideggeriano, cada parte tem um elo fundamental com a subsequente, fazendo da obra um todo que se complementa na discussão sobre o sentido da vigência do ser. Todas as suas junturas têm um mesmo anseio: conjugar-se para trazer à tona o modo de (des)velamento da verdade no tempo-espaço do ente, fundando-o a cada vez e a cada época histórica em que se acena. 


\section{A VIGÊNCIA DO SER NA TRANSIÇÃO AO OUTRO PRINCÍPIO DO PENSAMENTO}

Em suas meditações filosóficas na obra Contribuições à filosofia, Heidegger não pensa o ser nos moldes da tradição ontológica, isto é, sob a dimensão da entidade do ente. Essa forma de modulação metafísica é ultrapassada, uma vez que o ser (Seyn) se doa ele mesmo sem interferência do ente e, portanto, "mostra-se" em sua própria verdade, vige por si mesmo, sem intermediários.

Nas Contribuições à filosofia - como foi salientado em nota de rodapé, mas voltamos a relembrar o leitor - "seer" é a tradução portuguesa arcaica de Seyn. Lembramos também que optamos por usar "ser" em nosso texto, todavia, evidenciando que estamos nos referindo ao ser (Seyn) em sua profunda diferença com o ente. De toda forma, aqui cabe dizer que o termo da língua portuguesa arcaica indica o acontecimento apropriador que acomete os entes. "Seer", com grafia diferenciada, evidencia que o fundamento é totalmente outro, não manipulável pelo cálculo ou pela técnica. Representa a própria diferença ontológica (ontologische Differenz) ${ }^{5}$ entre sua essenciação apropriadora e o ente. Ele se dá em acontecimentos no tempo em cada época. Assim, a questão acerca do sentido do "ser" em Ser e tempo (Sein und Zeit, 1927, GA

2) agora se torna a questão acerca da verdade do ser (Seyn) nas Contribuições à filosofia. Em Ser e tempo, "foi anunciado [...] algo assim como uma precedência do Dasein" (HEIDEGGER, 2012, p. 49). Heidegger destaca este determinado ente entre todos os outros, posto que ele é capaz de perguntar pelo sentido do que o sustenta. Desse modo, o ser-aí (Dasein) é um ente privilegiado não porque é um animal que pode julgar racionalmente, mas porque tem a possibilidade de meditar a respeito da vigência que o faz ser si mesmo, isto é, constituir-se como ser singular. Compreendemos que o ser-aí não é o homem, mas é o em-meio-ao homem, aquilo que o torna eks-istente ${ }^{6}$ a cada vez. Completa Heidegger:

\footnotetext{
5 “A expressão die ontologische Differenz foi introduzida, pela primeira vez, em 1927 para marcar a distinção entre (SER (das) Sein) e ente (das Seiende)". A distinção, e não a expressão, é central em ST [Ser e Tempo] [...] A palavra Differenz, do latim differo (lit. carregar, levar lado a lado, apartado um do outro), implica que 'os entes e o ser se levam apartados um do outro, separados e, ainda assim relacionados um com o outro - e isso espontaneamente, não meramente na base de um 'ato' de 'distinção' ['Unterscheidung']'. Heidegger também fala da Unterscheidung entre ser e entes. Em seu sentido literal, differo é próximo do alemão austragen, 'carregar para fora, entregar, lidar com, arranjar'. Austrag é o 'arranjo, resolução [p. ex., de uma disputa]'. Portanto, a Differenz de ser e entes é também uma Austrag deles, que os reúne ao mesmo tempo que os mantém separados" (INWOOD, 2002, p. 42).

${ }^{6} \mathrm{O}$ termo eks-istente indica o modo essencial de ser do ser-aí (Dasein). Ele eks-iste porque, temporal, é ex-pectativa, futuridade, mas, outrossim, memória. Muito mais do que presença, o ente humano é um ser ausente em sua dimensão ex-tática. Ao mesmo tempo, essa dimensão explica o quanto o seraí é finito, não sendo o seu próprio fundamento. Daí o motivo pelo qual ele é um "buscador", porque, em sua pobreza, ex-teriora-se insistentemente de si ao fundamento que lhe permite ser a cada tempo.
} 
Se o Dasein, por outro lado, tomou a possibilidade que tem de não só dar transparência a sua existência, mas também de perguntar pelo sentido [...] do ser em geral [...] então ele verá, inevitavelmente, que o perguntar pelo ser [...] é caracterizado ele mesmo pela historicidade. (HEIDEGGER, 2012, p. 83, grifo meu)

Como se vê em Ser e tempo, o ser-aí "toma" para si a tarefa de perguntar pelo ser. Nas Contribuições à filosofia, a pergunta pelo ser, na verdade, já é uma resposta à silenciosa voz e à provocação do fundamento. O ser-aí não cessa a sua tarefa, continua insistente no questionamento acerca do sentido do ser, mas porque, primeiramente, o mistério que o apropria se doa em retração essencial e o presenteia com o seu (des)velamento.

A essência da verdade, no outro princípio do pensamento, passa a ser interrogada a partir da vigência principial, essa essência que se encobre como revelação-ocultante. A pergunta acerca do ser não é pensada a partir do ente, mas é postulada, necessariamente, como o repensar do ser por meio da verdade do ser mesmo. No entanto, não se trata de ser na perspectiva metafísica da tradição (ser do ente, entidade do ente), mas a indagação se arroja no esforço de pensar o acontecimento essencial mais originário a respeito dessa verdade. Aqui, trata-se de um acontecimento apropriador fundamental (Ereignis).

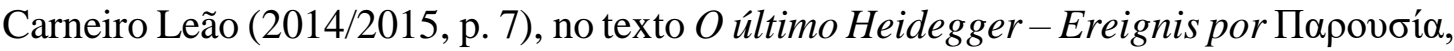
evidencia a sua interpretação de Ereignis. Esse evento essencial aparece como "a gratuidade da Abertura de Acontecer, como o instante de uma visita". O modo do Ereignis se apropriar do homem não se dá por meio da força, ao contrário, acontece como sein-lassen (deixar-ser). É um processo de abertura que se abre, desvela-se e se deixa acontecer; que se mostra e se faz visível ao ser-aí. É um processo ímpar, pois ele faz aparecer, desencobre-se e re-vela-se. No entanto, a revelação aqui é que faz o acontecimento do Ereignis retrair-se para o velamento. Revelar-se é velar-se novamente. Ereignis, portanto, indica o abrir-se do aberto (Offene), o desvelar-se essencial do fundamento que tão logo bate em retirada.

Esclarecendo o étimo da palavra, acontecimento apropriador é uma expressão originária do alemão Ereignis presente na obra Beiträge zur Philosophie. O termo indica, comumente, acontecimento, ocorrência, evento como aquilo que produz um efeito, hábil a se tornar um modelo ou paradigma comportamental. Quando se lê o termo Ereignis, entende-se apropriação graças ao sufixo eignis derivado do adjetivo eigen (próprio). Tal entendimento (próprio, apropriar, apropriação) não é incorreto, mas não ingressa na essência do pensamento 
de Heidegger. O acontecimento como apropriação é uma compreensão que não atinge a raiz da questão ${ }^{7}$.

A origem do termo Ereignis é:

auge, o olho, donde se derivou er-äug-nis, através do verbo äugen que, primeiramente, grafava-se e pronunciava-se tanto äugen como eigen. Eram dois homônimos quase homófonos, mas de significado diferente: ora designava o processo de dar vista, de colocar à vista dos olhos. Segundo este étimo, o primeiro uso de Er-eignis é pôr à vista, mostrar. Aqui, Er-eignis nos transmite um processo que se abre e se deixa ver, que se mostra e ostenta, possibilitando a visão, que dá, portanto, visibilidade, tornando possível uma visão. Trata-se de um processo que faz aparecer e deixa sair do encoberto [...] E somente por manifestar e mostrar é que Er-eignis pode significar, em decorrência, evento, acontecimento, ocorrência, mas primordial e, principalmente, designa processo de fazer aparecer, de dar lugar, de re-velar ser. (CARNEIRO LEÃO, 2014/2015, p. 16)

$\mathrm{Na}$ filosofia heideggeriana, Ereignis passa a ter um sentido específico e originário: dar lugar, deixar-ser, abertura de ser. O termo, assim utilizado, possibilita pensar eigen na sua interpretação originária de äugen como o tornar-se visível, o fazer-se ver e o deixar-ser (seinlassen). Levando-se em conta o sentido fundamental da palavra Ereignis, os acontecimentos epocais propiciam que, no decurso da história, o mistério e a simplicidade do ser venham à tona, mostrando-se, desvelando-se.

No evento radical (primordial) do ser (Seyn) não acontece exclusivamente apropriação, mas des-apropriação (Ent-eignis), isto é, recusa, pois o advir do ser, em seus próprios modos, parte do deixar-acontecer de sua constrição, em seu esplendor fundante e fundamental. É o mistério singelo do ser manifestando a sua verdade como acontecimento apropriador. Heidegger, na seção 254 das Contribuições à filosofia, explicita:

O que aconteceria se [...] o seer precisasse ser concebido, pela primeira vez, em sua verdade, como o acontecimento da apropriação, acontecimento esse como o qual acontece apropriadoramente aquilo que denominamos a recusa? Isso não é nem fuga nem chegada [...], mas algo originário, a plenitude da concessão do seer na recusa.

A recusa é a nobreza mais elevada da doação e o traço fundamental do encobrir-se. (HEIDEGGER, 2015, p. 392, grifo do autor)

\footnotetext{
7 Cfr. CARNEIRO LEÃO (PIZZOLANTE, Rômulo, Org.). O último Heidegger (Ereignis por

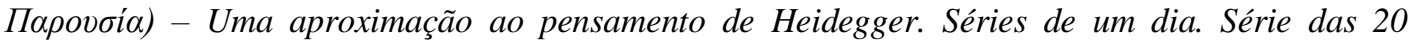
conferências de Emmanuel Carneiro Leão - 2014/2015, p. 7.
} 
O acontecimento apropriador (Ereignis) é, simultaneamente, des-apropriador (Enteignis), uma vez que se dá como vigência ontológica principiante, abertura fundamental na dimensão dos entes, advindo como recusa, a reserva essencial que se ostenta em constrição. É o constante "ir embora" do princípio não como fuga ou chegada, mas como doação essencial

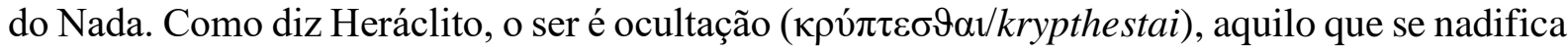
no vir à tona dos entes.

O Ereignis, o seu modo de apropriação do ente, traz a possibilidade de abertura para o sendo da presença humana. A própria vigência do ser na dimensão do ser-aí representa a apropriação deste e, assim, o ente é fundado pelo encobrimento-clareador. No entanto, Heidegger deixa claro que o ser não está ao redor do ser-aí e também não o percorre como um ente. Este último é apropriado e fundado em meio ao acontecimento fundamental, pertencendo ao acontecimento apropriador. Ereignis é a sustentação vigorosa de abertura que estrutura acontecimentos epocais. É a edificação, o princípio, a inauguração dos acontecimentos do ser, do seu realizar-se. Dessa forma, podemos concluir que o que há é a história do ser (Seynsgeschichte), que se dá novamente e sempre de novo, edificando outros percursos, passagens, esforços, dinâmicas e desafios ao ser-aí.

O pensamento ocidental agora se volta a outra questão a partir da indagação das Contribuições à filosofia. Abre-se à passagem para outro princípio (anderer Anfang). Irrompe uma transição fundamental para um pensar originário: o pensar "sobre" o ser, isto é, o pensar do acontecimento apropriador (Ereignis). Aqui, nessa visão, de pronto podemos indicar que o nosso questionamento se refere ao aceno (Wink) oriundo do que é digno de estar em questão por nos ser íntimo e primordial: Seyn. Dá-se esse espaço, essa liberação, pois “a filosofia precisa ter empreendido algo essencial em meio à transição para o outro princípio: o projeto, isto é, a abertura fundante do campo de jogo tempo-espacial da verdade do seer" (HEIDEGGER, 2015, p. 8). Todavia, surge a pergunta: como transitar para o outro princípio? Há um pioneiro, aquele que prenuncia essa tarefa? E qual é o esteio que sustenta essa transição, esse passe (das Zuspiel)? Em resposta ainda não definitiva para o que foi indagado, Heidegger demonstra que os projetos historicamente conhecidos são significativos, mas não são suficientes para a transição desejada. O que pode realizá-la é a de-cisão (Ent-scheidung) da filosofia em deixar de persistir na negação da dignidade do ser para se direcionar ao que há de mais digno de questão no outro princípio do pensamento.

O outro princípio do pensamento, segundo Heidegger, não é assim intitulado para determiná-lo como uma opção transcendente, superior ao que a história ocidental propôs durante as diversas épocas, tampouco possui uma forma distinta do 
que qualquer outro pensamento filosófico conserva. Mas esse outro princípio deve ser outro por ser originário, unido ao princípio uno e primeiro (erster Anfang). A transição não representa a negação do que até aqui se deu na história, mas se trata de uma articulação bilateral de um princípio da tradição do Ocidente com o princípio dessa outra meditação. Esse pensamento transitivo se pauta no projeto fundante da verdade do ser (Wahrheit des Seyns) como um pensar histórico. Se a história parte do pensar meditativo, ela não é um mero objeto, mas é, prioritariamente, aquilo que desperta o questionar, sendo o sítio da tomada de decisões a partir de seus envios.

O que é significativo em Heidegger é a sua disposição a um grande e complexo labor nessa perspectiva do pensamento no interior da transição do primeiro princípio (metafísica) ao outro princípio do pensar (guarda do mistério do ser). Primeiro, porque o pensador ingressa na discussão a respeito da vigência do ser tradicionalmente inquestionada por mais que a história seja a história do ser - embora, a partir de seu esquecimento, a entidade do ente tenha assumido o primado. Segundo, porque na transição, o primeiro princípio é digno de ser levado em consideração, todavia, por outro lado, deve ser suplantado. Eis o grande polémos na questão: "No saber do pensamento inserido na transição, o primeiro início permanece decisivo como primeiro e é, entretanto, superado como início" (HEIDEGGER, 2015, p. 9). A turbulência no projeto está em “olhar para trás", para as realizações da tradição, mas, também, no "ir além esse olhar" para existir a possibilidade de outro questionar e dizer. Aqui está o grande desafio.

Nota-se que o estilo vigente que modelou as pesquisas filosóficas não são o norte para as Contribuições à filosofia. Heidegger esclarece que a questão do ser é, na verdade, a pergunta a respeito da verdade do ser (Wahrheit des Seyns). Essa pergunta aponta para a questão fundamental (Grundfrage) sobre como o ser se essencia. Para respondê-la, as Contribuições à filosofia reforçam que ser não é representável. Ele precisa ser descoberto pelo pensamento a partir do seu próprio desvelamento. Isso significa que não é o ente o desvelador de ser, já que "onde quer que um ente apareça, o seer já sempre se apropriou desses fundadores" (HEIDEGGER, 2015, p. 11). Os que atribuem a história a si mesmo, antes de tudo, são fundados por meio da essenciação principial, pois se trata de um acometimento que se apropria do ser-aí. Heidegger (2015, p. 11) utiliza a expressão "ligação volteante do seer com o ser-aí" (des kehrigen Bezugs des Seyns zu dem ihm ereigneten Dasein) como uma entrega apropriadora de um ao outro, uma relação recíproca do ser com o ser-aí. Embora a revelação do aberto (Ereignis), esse acontecer que se doa perfaça a essenciação originária, surge um risco a esse evento, já que ser inicia a recusa ao acometimento do homem porque este perde 
a força para o ser-aí por consequência da maquinação, isto é, por resistência da técnica.

A questão é que devemos ter em mente que o ente é, enquanto o ser vige. Disso surgem outras questões: como o ser vige? Ao viger, torna-se um ente? Que outra instância decide o pensar? Nenhuma outra dimensão direciona o pensar senão o ser que se essencia. Heidegger insiste: o ser não pode ser mais pensado a partir do ente. Ele precisa ser descoberto a partir de si mesmo. Faz-se necessário abrir, radicalmente, o pensar do setor objetivo do ente e das concepções de mundo, que é justamente o que a virada da filosofia heideggeriana permitiu como o seu escopo para se situar na abertura ao outro princípio. A problemática aqui é que esse outro âmbito não está definido, conceituado ou objetivado. Ele é abissal, porque não está dado ou instituído como um solo formado e pronto para se habitar.

O pragmatismo moderno, as respostas das diversas ontologias vitalistas, idealistas, volitivas, empiristas, científicas aqui passam a ser suspeitas, já que se tornam inautênticas e ilegítimas, dado que instauram uma visão de prontidão e acabamento a partir do momento em que suas resoluções advêm do entitativo (dimensão do ente), distanciando-se da originariedade do ser. Essas respostas firmes e sólidas da metafísica se tornam suspeitas no outro limiar, já que o modelo metafísico se esgotou. O esgotamento ontológico das explicações filosóficas se dá porque chega o seu "fim". Os sistemas e métodos tradicionais não dão conta da simplicidade do ser e, igualmente, não suportam a transição ao outro princípio. Assim, há duas vias: se cai e decai cada vez mais no nada ${ }^{8}$ da ausência de indigência do pensar, que indica mergulhar no mundo do ente e tê-lo como origem do fazer e do produzir, esquecendo-se da iluminação velada do ser; ou o homem se abre para o outro princípio, apropriando-se das palavras do primeiro princípio, mas não as tendo como leis a serem seguidas, já que essa retomada não é o ponto de inércia na tradição filosófica e sim de transição para um pensar estranho, irresoluto, todavia, originário e fundamental.

Mas quem poderia estar disponível e aberto a tal sacrifício? A abrir mão da magia encantadora do mundo dos entes para se dirigir ao estranho e ao inóspito da instância do ser $($ Seyn)? São aqueles aos quais Heidegger chama de "os vindouros", livres para o fogo do que se aguarda e, assim, o ser-aí (esse que nada produz, porque espera o desvelar-se essencial do ser) venha a ser possível para o homem. Os fundadores (pensadores e poetas) só podem fundar porque foram fundados previamente. Os vindouros são fundadores e, por conseguinte, são raros, pois acolhedores de sua facticidade (pobreza, indigência e finitude), recepcionam o ser de bom

\footnotetext{
${ }^{8}$ Trata-se do nada no âmbito existentivo, isto é, nas condições funcionais do ente.

${ }^{9}$ Cfr. HEIDEGGER, Martin. Seção 5. Para os poucos - para os raros. In: Contribuições à filosofia (Do acontecimento apropriador), 2015, p. 15.
} 
grado, guardando-o e protegendo-o por meio do pensamento e da linguagem poética. Isso se esclarece quando Heidegger (1967, pp. 24-25) escreve em Sobre o humanismo (Über den Humanismus, 1946, in Wegmarken, GA 9): “A linguagem é a casa do Ser. Em sua habitação mora o homem. Os pensadores e poetas lhe servem de vigias [protetores]. Sua vigília é consumar a manifestação do Ser, porquanto, por seu dizer, a tornam linguagem e a conservam na linguagem”. Con-sumar aqui não indica esgotar o Ser, mas deixar a sua vigência se plenificar, permitir que o mistério do Ser se dê como serenidade (o vir a ser como pura abertura).

Se a abertura originária é anterior ao que é ôntico, o pensar "chega tarde", porque ser o precede e o possibilita. Todavia, o pensar "chega junto" ao acometimento originário uma vez que dessa vigência recebe doação. Eis a ambiguidade do acontecer do pensamento, que tardiamente-junto se dá com a essenciação fundamental. Tal movimento é exigência do ser mesmo. Mas o ser se dá naqueles que experimentam o ocaso onde quer que a força do ente ainda permaneça. Isto é, a "consciência" de que a era da metafísica do primeiro princípio chegou ao seu esgotamento e que se inicia o período de um outro princípio onde "o seer já sempre se a-propriou desses fundadores [...] Essa é a essenciação do seer mesmo: nós a denominamos o acontecimento apropriador" (HEIDEGGER, 2015, p. 11). Aqui se trata de uma plenitude indeterminável e incalculável por qualquer epistemologia, filosofia da ciência, lógica e até mesmo pela estética que trata de saberes distintos do lógico-racional do mundo maquinalcalculador.

O que Heidegger faz nas Contribuições à filosofia, nessa outra forma de questionar e pensar, é apresentar a conexão de jogo do primeiro e do outro princípio a partir da ressonância (der Anklang), o ecoar do ser no acometimento do ser-aí. Aqui, o ser é pensado e questionado a partir da indigência do abandono do ser (do primeiro princípio) para o salto (der Sprung) à instância do ser (do outro princípio). Salto porque não se trata de uma passagem moldada por sistemas ou métodos lógicos. Esse salto tem como função significativa propiciar a "fundação" (die Gründung) da verdade do ser dos que estão por vir. A palavra "fundação" está entre aspas porque se busca expressar que o ser-aí (Dasein) nada funda, mas é fundado e destinado a fazer parte da história como aquele que é apropriado pela abertura do fundamento: Seyn.

Heidegger se situa em outra forma de pensar, o que o autor intitula pensar diretivo ${ }^{10}$. Essa diretiva nos aponta um outro caminho, o pensar meditativo, o que indica a abertura da verdade do ser em meio ao ente, sem ter o caráter de uma ordem. Não o é, pois se esse acometimento fosse um imperativo que parte de uma doutrina, seria metafísico e o

${ }^{10}$ Cfr. HEIDEGGER, Martin. Seção 2. O dizer do acontecimento apropriador como a primeira resposta à questão do ser. In: Contribuições à filosofia (Do acontecimento apropriador), 2015, p. 11. 
ser estaria sob o mandamento do ente, o que não acontece em hipótese alguma no pensamento das Contribuições à filosofia. Nunca esse pensamento pode ser transmutado para o ordenamento de uma lei entitativa (ordenamento do ente). Ele escapa a esse saber não sendo atingido por opiniões, concepções de mundo ou por vivências. Essa diretiva do pensamento do outro princípio se subtrai e, além disso, dá um encaminhamento aos poucos (os que estão por vir, os vindouros), aqueles resgatados da amálgama das definições do ente.

Mas aqui encontramo-nos com o perigo. É no acontecimento apropriador que o ser se perfaz essenciando-se no ente. $\mathrm{O}$ perigo reside na recusa do ser em essenciar-se, recusando o acontecimento apropriador, porque o homem se enfraquece essencialmente e não se insere no aberto. Isso se dá graças à violência provocada pelo afã da técnica em sua massificação (gigantesco) que gera uma dominação entitativa planetária nos dias de hoje. Se isso ocorrer, se o acontecimento apropriador se tornar recusa, denegação, isso indica uma mera e simples retração do ser e o total abandono do ente ao não-ente, gerando um niilismo extremo? Ou será que essa denegação (ausência originária) pode se doar como o mais extremo dar-se do ser (es gibt Seyn), como acontecimento apropriador? Esse evento poderia apresentar ao homem o temor (reverência) frente ao não originário, fazendo essa ausência, na verdade, ressoar a tonalidade afetiva fundamental da retenção (Verhaltenheit) do ser? Isso direcionaria o homem para a abertura do fundamento e o exporia ao ser-aí? A resposta é sim, pois como diz Heidegger (2001, p. 31) no texto A questão da técnica (Die Frage nach der Technik, 1953, in Vorträge und Aufsätze, GA 7), levando em conta os versos de Hölderlin: “Ora, onde mora o perigo é lá que também cresce o que salva". O perigo que a maquinação traz como culminação do gigantesco pode ser o ápice da retração do ser. Esse não é o que pode gerar o quebramento do quantitativo do ente para a abertura do fundamento. O filósofo, ainda no texto A questão da técnica, salienta: "Do mesmo modo em que a natureza, expondo-se como um sistema operativo e calculável de forças pode proporcionar constatações corretas, mas é justamente tais resultados que o desencobrimento pode tornar-se o perigo de o verdadeiro se retirar do correto" (HEIDEGGER, 2001, p. 29).

$\mathrm{Na}$ indicação sobredita há dois grandes perigos: o não do ser para o ser-aí e o correto impedindo o homem de "ver" a verdade. O primeiro perigo indica a abertura originária se fechando para o homem por causa da maximização da técnica, o que promove o desenraizamento do que é principial (anfänglich). O segundo perigo se dirige ao próprio da culminância da maquinação, ao gigantesco, na medida em que a verdade (Seyn) se desapropria do ente e o essencial perde espaço para a correção. Isso indica a queda do ser e o aumento da vitalidade do ente? Pelo contrário, significa uma palidez, 
ausência de dignidade, perda da origem por causa das grandes metas da maquinação, que faz o ser decidir pela ausência. Porém, essa retração não deixa de ser acontecimento apropriador (Ereignis), tendo em vista que ainda assim, ser se essenciou.

A salvação frente ao perigo está em pensar a essência como Ereignis, aquilo que traz o "risco" da recusa. Essa negação pode ser melhor compreendida acolhendo-se o ser como uma genuína abertura. Daí a conexão de jogo da pergunta sobre o ser, que coloque em jogo o outro princípio (metafísica), denunciando os perigos de se permanecer na violência da maquinação nos posicionamentos do ente. Assim, há o salto para o outro princípio (meditação acerca do ser), que indica os limites e o esgotamento da metafísica, demonstrando o esfacelamento das modulações ontológicas usuais. Se chegamos a esse ponto da história, se está havendo uma transição antes nunca vista na história do Ocidente, um salto ontológico que ruma a outro princípio do pensamento, as questões, igualmente, devem sofrer alterações. Assim, como demonstrará a próxima seção, o perguntar e o perguntado se tornam outros e as respostas metafísicas já não são suficientes para representar o que é originário.

\section{A TAREFA DAS CONTRIBUIÇÕES À FILOSOFIA: A PERGUNTA SOBRE O ORIGINÁRIO}

O espanto ${ }^{11}$ é, desde os gregos, o humor básico que leva o ente humano a perguntar sobre o sentido do ser. O princípio da filosofia ocidental que permite essa interpelação, segundo Platão e Aristóteles, é a admiração, o estupor (Erstaunen), aquilo que leva o homem a buscar resoluções para as suas aporias. No outro princípio que se anuncia no Ocidente, o espanto como temor (Erschrecken) é a tonalidade afetiva fundamental, indicando a prontidão e a insistência do ser-aí na essenciação do ser.

O espanto: ele precisa ser elucidado, antes de tudo, em contraposição à tonalidade afetiva fundamental do primeiro início da metafísica, à admiração [...] O espanto é a viagem de volta do caráter corrente do comportamento no familiar para a abertura do acometimento do que se encobre. (HEIDEGGER, 2015, p. 19)

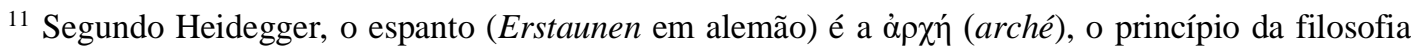

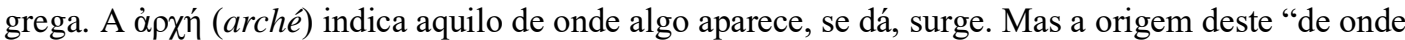

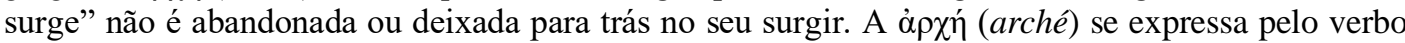

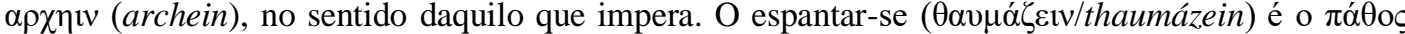
(páthos) do pensamento em seu primeiro princípio. Complementa Heidegger: "Assim, o espanto é a dis-posição na qual e para a qual o ser do ente se abre. O espanto é a dis-posição em meio à qual estava garantida para os filósofos gregos a correspondência ao ser do ente", isso na história do primeiro princípio (HEIDEGGER, 1973, p. 220).
} 
Como se vê, a tonalidade afetiva que funda o pensamento no outro princípio suporta um deslocamento (Versetzung): o espanto como temor é o que abre a possibilidade do ser se dar ao ser-aí não como presença dada, mas como realidade principial re-velada.

O espanto, no outro princípio do pensar, abre espaço ao perguntar originário (erfragen) sobre o mistério apropriador, que ostenta a vigência nadificadora. O questionamento traz à tona o pensamento originário acerca da verdade (Erdenken der Wahrheit). A verdade do ser é o perguntado (Erfragte) pelo pensar que surge da tonalidade afetiva do assombro como temor (Erschrecken). Segundo Ramos (2015, p. 140): “[...] o Erfragte será aquilo que se subtrai radicalmente a todo e qualquer substancializar". Disso, podemos compreender que o perguntado não está dado à mão como um ente, mas está livre de qualquer possibilidade de caracterização ou modulação técnica. Não se questiona sobre ser no âmago de entidade, mas pergunta-se pelo ser mesmo. Ou melhor, questiona-se sobre o ser depois que ele já se deu, apropriando-se do questionador.

As Contribuições à filosofia se colocam em função da única pergunta fundamental acerca da verdade do ser (Seyn). Essa pergunta sobre o originário é espantosa, pois caminha a um vazio indeterminado, haja vista que o caminho ainda não foi trilhado. Não se sabe o que é o outro princípio claramente, apenas se tateia, paulatinamente, esse outro percurso fundamental da história ocidental, que agora se dá na contemporaneidade. Isso significa uma solicitação do ser que está em total in-decisão, porque o outro princípio ainda se dá como pressentimento, como suspeita (Ahnung). Mas, ao mesmo tempo, é um perguntar sereno, tendo-se em vista que se trata de uma abertura do ser-aí ao mistério do aberto que começa a se dar. É o acolhimento e guarda do dizer originário, o deixar-ser dos acenos da possibilidade das possibilidades. Esse perguntar, para Heidegger, desperta para a suspeita de que as modulações sistemáticas ocidentais caíram na consistência do esquecimento do ser. Assim, há quem diga que o perguntar aqui proposto parece ser um desprendimento de tudo, inclinando-se a uma meditação inerte. O indagar sereno dá a aparência de ser algo inibidor e restrito, pois desinstala o ente do domínio da história do esquecimento da senda abissal. No entanto, ele não é cerceador, já que a pergunta do outro princípio se dirige ao indômito, aquilo que ainda não foi pensado e necessita ser ponderado com sensatez. Busca-se ir além do dado e do instituído, daquilo que ultrapassa o mundo dos objetos não por ser transcendente como uma ideia essencial, mas porque se ausenta como ocultação-clareante. Esse "perguntar é a liberação para o que impõe em seu velamento" (HEIDEGGER, 2015, p. 14). 
O espantoso e o sereno perguntar são respostas ao aceno do indômito. Aquilo que calcula e contabiliza os objetos no mundo do ente não contabiliza o perguntar sobre a verdade do ser. A indagação aqui deve preparar para o princípio de outra história e a sua execução escapa das derivações conceituais, dirigindo-se para o que é originário: Seyn. Esse perguntar é espantoso, pois o ser-aí "descobre" que o fundamento da realidade é nulo por não ser objetivo, por não estar imbuído de características materiais. Acontece que tudo à volta do ser-aí deve ser reconsiderado e o perguntar deve levar em conta a sua indigência, o que significa dizer que não somos o fundamento e que, pelo contrário, somos fundados pelo não do ser. Aqui há serenidade: o percebimento dos nossos limites, da indigência de nossa facticidade (Faktizität). Não só o perguntar é espantoso como as respostas que vão surgindo a partir da abertura do caminho do outro princípio também espantam à medida que vão situando o homem na sua finitude e a sua origem na ausência da abertura elementar. No entanto, para suportar, insistir na travessia ao outro princípio e no caráter de nulidade do fundamento, o homem precisa ser sereno, compreender o seu grau de pobreza perante o que o torna ente.

Vivemos em uma era da carência, que se dá a partir da indigência velada na era da maquinação globalizante. Trata-se de uma indigência velada, pois não nos alertamos de que a autocompreensão de que somos o próprio fundamento da existência em sua totalidade parte de um desvio do olhar, da indigência do pensar, já que nada mais é perguntado, mas tudo é feito, produzido e calculado para mais se fazer e produzir. Daí surge a tarefa das Contribuições à filosofia: "A pergunta sobre o 'sentido do seer' é a pergunta de todas as perguntas" (HEIDEGGER, 2015, p. 14). A questão do ser em Ser e tempo, agora, nas Contribuições à filosofia, é um salto para o interior (Einsprung) do ser. Quem o faz de forma significativa é o poeta, já que este não se apresenta com força desmedida para calcular e manipular a vida, mas, poetizando, guarda abertura ao aberto.

Os poetas seriam os poucos, os raros, que de tempos em tempos perguntam pelo essencial, pelo fundamento e decidem, de forma renovada, pela dignidade da essência da verdade. Os raros, corajosos para a solidão, a fim de pensar, perguntar e falar pela nobreza do ser (Seyn). Esse acolhimento por parte dos raros, da essenciação do ser como acontecimento apropriador, necessita ser intrépido, pois ainda não sabemos qual é o real desafio de nossa época, já que o outro caminho é uma via inteiramente outra, aberta e desconhecida. Em relação a isso, esclarece Heidegger (2015, p. 16): “o desconhecido que nos é dado como tarefa deixa a vontade na solidão e, assim, obriga a existência do ser-aí à mais elevada retenção em relação ao que se oculta". Ou seja, a vontade humana - como a vontade de potência em Nietzsche, que a tudo retém e domina - em Heidegger deixa de ser a autora das 
construções históricas para ser uma manifestação daquilo que se oculta ao acometer o ser-aí. O que se desvela como um raio e que logo se retrai é o ser, portando a própria medida e constância em si, se é que de fato o ser precise de alguma medida.

Heidegger compreende que ainda recairemos no perguntar e no responder metafísicos por bastante tempo, impedindo-nos, por vezes, de ir além das margens do ente. "Não obstante, o instante histórico da transição precisa ser levado a cabo a partir do saber de que toda metafísica (fundada na pergunta diretriz (Leitfrage): ‘o que é o ente?') permanece sem condições de voltar o homem para as ligações fundamentais com o ente" (HEIDEGGER, 2015, p. 16). Enquanto a ontologia tradicional pergunta “o que é o ente?" na questão condutora (Leitfrage) prevalecente desde a filosofia helênica até a sua consumação em Nietzsche, o outro princípio, com a proposta de superação da condução filosófica metafísica que, historicamente, esqueceu o ser, dirige-se à pergunta fundamental (Grundfrage): "como se essencia/vige o ser?", "como há acontecimento apropriador?". O passe do pensar da Leitfrage (ser sob a perspectiva da entidade) ao pensar da Grundfrage (meditação acerca da vigência constritiva da verdade) representa passagem, transição, conexão de jogo entre o primeiro princípio (filosofia como metafísica) e o outro princípio (pensar como meditação sobre o ser). No entanto, um questionamento precedente ao salto suplantador é apontado. Referimo-nos à pergunta preliminar (Vorfrage) "o que é a verdade?" (Was ist der Wahrheit?). Se a verdade para a história da metafísica é a própria presentidade, no outro princípio, a verdade é ausência fundamental.

Para Heidegger, os pressupostos ontológicos do primeiro princípio começam a se

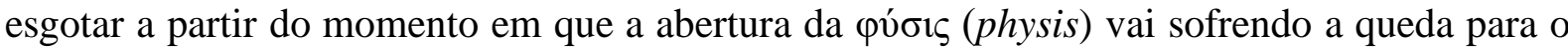
aspecto, o que acontece durante a história da filosofia. Mas, na atual conjuntura de maquinação do ente, estamos preparados para a pergunta espantosa e, com serenidade, conseguiremos pensar a verdade do ser? A linguagem do ente, na qual estamos sempre situados, consegue partir para essa tarefa? Não há respostas definitivas sobre essas questões, no entanto, de uma forma ou de outra, no outro princípio do pensamento ocidental que se prenuncia, a abertura à vigência originária se torna necessária e digna por aqueles que estão dispostos ao espantoso e ao sereno perguntar. "Eles são os crentes propriamente ditos, porque eles se mantêm - abrindo a essência da verdade - sobre o solo" (HEIDEGGER, 2015, p. 17, grifo do autor). Os crentes são fundadores, pois perguntam, abrem-se ao pensamento. Ao poetizar, são solícitos e insistentes no ser. São solitários, ausentes de artifícios maquinais. Entretanto, por que os crentes são fundadores? Porque, antes de tudo, são apropriados pelo fundamento (Seyn). Eles questionam, abandonam o falatório e a curiosidade da cotidianidade média. A avidez à publicidade é recusada. A busca desses raros representa o amor ao abismo que, para 
os "muitos", é assombroso e terrível, para os "poucos" (raros) é o mais antigo fundamento que se dá a partir da postura serena do perguntar. Para esses vindouros, o espantoso é sinônimo de grandiosidade e raridade do fundamento, indicando o quão sereno é o ente raro (ser-aí). Para o homem comum, o espantoso é um colapso, um não, uma ausência sem espaço para abertura. Para o ser-aí, o espanto é a disposição para o que há de mais singelo.

De que modo essa abertura (Seyn), que não é ente e que se retira de toda maquinação possível, pode se dar ao perguntar do ser-aí? Heidegger responde (2015, p. 17): “O seer não é algo 'anterior' - subsistindo por si, em si -, mas o acontecimento apropriador é a coetaneidade tempo-espacial para o seer e o ente". Em outros termos, o ser se dá no ente. Não é possível existir acontecimento apropriador e história a não ser pelo dar-se do ser no campo ôntico, isto é, na concretude fáctica do ente humano. Por esse motivo é possível o espantoso perguntar pela essência da verdade, já que ser acomete o ser-aí nos seus envios históricos.

Ao refletir sobre a historicidade do ser-aí como uma fundação essencial da vigência originária em campo ôntico, Heidegger não busca fazer representações ou conceituações do ser. Pelo contrário, o projeto fundamental das Contribuições à filosofia é perguntar pelo sentido do ser, mas não dar uma resposta a essa questão, uma vez que responder em definitivo é característica do pensar metafísico, que durante a história buscou solo seguro nas modulações do ente. Na próxima seção, veremos como a filosofia de Heidegger não se apresenta como uma disciplina ontológico-filosófica sobre o ser, mas se mostra, essencialmente, como uma meditação histórica que deixa a verdade se dar na perspectiva de abertura indefinida do porvir.

\section{A MEDITAÇÃO HISTÓRICA APONTA PARA UM PENSAR VINDOURO}

Quando Heidegger se põe a perguntar sobre a verdade originária, discorrendo acerca da história do ser (Seynsgeschichte) e sobre a sua vigência, o filósofo não a compreende a partir da instância do sendo dos entes. A referência aqui é a própria vigência principial (Пароvбía ${ }^{12} /$ parousía, Ereignis), ausente de semântica historiológica: história como mera

\footnotetext{
${ }^{12}$ Emmanuel Carneiro Leão, na série das 20 conferências sobre Heidegger e o Ereignis por П $\alpha \rho o v \sigma i ́ \alpha$ de 2014/2015, П $\alpha \rho 0 v \sigma i \alpha$ (parousía) é interpretada como um acontecimento originário criador, que em seus acometimentos se abre e se doa, mas, nessa abertura ( $\dot{\alpha} \lambda \hat{\eta} \vartheta \varepsilon \imath \alpha /$ alétheia), retira-se e encobrese. П $\alpha \rho o v \sigma i ́ \alpha$ (parousía) se dá como Ereignis (ser), que se apropria dos entes em desapropriação, já que a entidade é abandonada a si mesma diante da plenitude da abertura de ser. Ereignis aparece, portanto, como o grande abismo, o fundo e profundo desvelamento velado, o singelo mistério que se remete e acomete o homem. Cfr. CARNEIRO LEÃO (PIZZOLANTE, Rômulo, Org.). O último Heidegger (Ereignis por П $\alpha \rho o v \sigma i \alpha)$ - Uma aproximação ao pensamento de Heidegger. Séries de um dia. Série das 20 conferências de Emmanuel Carneiro Leão - 2014/2015, p. 8.
} 
ocorrência. Trata-se de pensar esse vigor como a plenitude do mistério que funda tempo-espaço (épocas e entes) e, dessa forma, funda a verdade. A partir dessa mirada originária, conquistamos uma compreensão essencial da história e entendemos que ela está além do poder, da ação e da vontade do ente. Ao entender essa estrutura do vigor fundante, fica esclarecido que o destino é pertencente à história, vigorosa e plena de possibilidades.

A distinção entre história (Geschichte) e historiologia (Historie) no pensamento de Heidegger é fundamental para entendermos a essência de cada uma delas. Por isso, diz Heidegger (2017, p. 17, grifos do autor): “Uma confrontação histórica [...] é algo essencialmente diverso de um cálculo historiológico". História é entendida como resultado da vigência do ser (Ereignis) que estrutura cada época, trazendo disposições afetivas que situam o ente no mundo. A história não se perde no passado, mas vige no presente e é decisiva para o futuro. Já a historiologia cientificiza a história a partir de cálculos dos eventos e fenômenos que

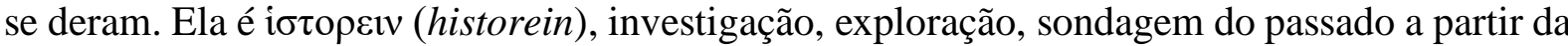
visão do presente. Contudo, "Pelo fato de um presente ser o presente e o hoje respectivo, ainda não se garantiu que os critérios atuais correspondem e estão à altura do que há de respectivamente grande em um passado" (HEIDEGGER, 2017, p. 48, grifos do autor). Com esse pensamento, Heidegger demonstra a limitação da historiologia, já que o presente-hoje é completamente diverso do presente-ontem. Dessa forma, os critérios de medida da historiologia podem não chegar ao elementar do que busca explorar.

$\mathrm{Na}$ continuação de suas meditações, Heidegger nos projeta à questão da meditação histórica (geschichtliche Besinnung) em distinção à consideração historiológica (historische Betrachtung). “A palavra 'geschichtlich' [histórico] visa ao Geschehen [acontecer], à história [Geschichte] [...] A palavra 'historiológico' designa um tipo de conhecimento”. Ora, vê-se como a meditação histórica se atenta ao acontecimento vigencial que se dá no passado, no primeiro princípio do pensar, mas que, outrossim, perpassa seu vigor ao presente, condicionando o futuro. Embora aqui haja uma conexão de jogo com o passado, a história não é vista sob a primazia dessa temporalidade, já que o acontecer histórico se dirige ao porvir (Zukunft), aquilo que constritivamente nos joga no êxtase da existência. Assim, "O porvir é o início de todo acontecimento" (HEIDEGGER, 2017, p. 51, grifos do autor). Já a consideração historiológica visa conhecer a história com os seus critérios e metodologias, tendo como direção de estudo o passado (Vergangenheit).

Heidegger não é avesso à consideração historiológica. O filósofo busca demonstrar como ela é sustentada por um pensamento essencial, mais originário, chamado de meditação histórica, amparado pelo acontecimento apropriador. Esta não 
busca conhecer, avaliar ou explorar, mas pensar o sentido da vigência fundamental estruturante do tempo-espaço do ente, que o lança no âmbito do porvir. Nesse sentido:

\begin{abstract}
Uma meditação histórica reconhecerá que não há simplesmente nenhum sentido em avaliar a doutrina aristotélica do movimento a partir dos resultados da doutrina do movimento em Galileu, em julgar a primeira como atrasada e a segunda como avançada [...] Computando de maneira historiológica, a ciência natural moderna é, com certeza, mais avançada do que a grega, se é que o domínio técnico e, com isso, também a destruição da natureza são um progresso. (HEIDEGGER, 2017, pp. 69-70)
\end{abstract}

A consideração historiológica se sustenta na comparação de resultados, hierarquizando doutrinas e avaliando realizações. O seu critério de medida pergunta pelo melhor, mais avançado e mais tecnológico. Dessa forma, as teorias físicas modernas seriam "melhores" do que as gregas. A física de Einstein superaria ambas as precedentes. Vê-se que a noção de progresso historiológico visualiza o que foi para notar o grau de seu desenvolvimento tecnológico nos tempos coevos. A meditação histórica, em contrapartida, aguarda, sem expectativa, um porvir indizível como acontecimento fundante. Nesse solo não há avaliação, critérios de medida ou hierarquização. "A meditação histórica [...] se encontra para além da oposição entre otimismo e pessimismo, pois ela não conta com a bem-aventurança de um estado de repouso do progresso ou mesmo com um retrocesso" (HEIDEGGER, 2017, p. 73).

A meditação histórica de Heidegger se encontra em um outro pensar que não se respalda na "lógica" trilhada pela história da filosofia, mas também não busca dizimar o pensamento das épocas precedentes. As meditações do filósofo apontam para um pensar ulterior, vindouro, a partir do qual a vigência do ser esquecida ou encoberta se dá ao pensamento, tornando-se digna de consideração. Aqui, o questionar (fragen) não exalta as objetividades rentes ao cálculo, à posse ou ao controle por parte da consciência. O escopo do indagar não é ter controle do mundo e de suas objetualidades, não é a busca do tratamento de uma coisa, mas sim a questão da apropriação. Esse outro pensar corresponde a uma modificação significativa do homem não circunscrito ao $\lambda o ́ \gamma o \varsigma$ (lógos), à consciência ou à concepção humanista de animal rationale, mas direcionado ao seu mais poder-ser como ser-aí (Dasein).

Heidegger, em suas interpretações acerca da história do esquecimento do ser pela técnica, não faz um diagnóstico detalhado da tradição ontológica para desenvolver um curso de filosofia, já que isso representaria a concatenação sistemática desta em disciplinas dos diversos posicionamentos do ente que surgiram durante os períodos de questionamento humano. Heidegger nos lança nas meditações esotéricas, que pensam o fundo 
originário a partir do qual todo ente é. Sua filosofia não é exotérica no sentido de ser uma teoria ou uma doutrina que recapitula e avalia a história. A esse respeito, na seção 5 das Contribuições à filosofia, lê-se:

\begin{abstract}
A questão pensante acerca da verdade do seer é o instante que sustenta a transição. Esse instante não é nunca efetivamente fixável, nem tampouco tem como ser contabilizado. Ele estabelece, pela primeira vez, o tempo do acontecimento apropriador. A simplicidade única dessa transição nunca é concebível historiologicamente, porque a "história" historiológica pública passou já muito tempo ao largo dessa transição [...] Assim, fica reservado para esse instante um longo caráter de futuro, contanto que deva ser quebrado ainda uma vez o esquecimento do ser do ente. (HEIDEGGER, 2015, p. 24)
\end{abstract}

O pensar a respeito da vigência (Seyn) é o que promove um outro sentido para a história, uma transição do sentido do ser, da entidade do ente para a verdade do ser. Contudo, não há uma data definida para o acontecimento dessa transição, um período exato a partir do qual podemos nos situar com rigor sobre tal, pois não se trata de um evento calculável e definido pelo ente. Trata-se, em verdade, do advento do acontecimento apropriador que acomete o seraí e, assim, instaura-se uma outra forma formadora na história. Essa doação originária que advém e sobrevém aos entes não pode ser concebida historiologicamente porque suas definições sistemáticas passam ao largo, ao longe do desvelamento ontológico da essência da verdade. O evento de transição do ser, desse modo, fica reservado ao futuro quando se cumprir a sua lembrança.

Heidegger se preocupa com a tendência de permanência do homem no âmbito da historiologia para se compreender os diversos caminhos que a história toma. A historiologia filosófica tem como ideal o conhecimento objetivo sobre os posicionamentos dos mais diferentes pensadores. Ela busca compreender os acontecimentos no dito dos homens. Mais fundamental do que tal procedimento, é compreender a historiologia como um evento histórico. É aqui que surge a grande aporia: o perigo iminente de acreditar fielmente que a historiologia é a "instância legítima de esclarecimento do sentido e essência da história da filosofia, como também poderia instaurar o acontecer dessa história" (RAMOS, 2015, p. 34). Pelo contrário, a história não pode ser entendida como resultado de concepções fundantes a partir da historiologia, já que, "a partir do acontecimento apropriador, acontece a apropriação de uma pertinência pensante e discursiva ao seer e à palavra 'do' seer” (HEIDEGGER, 2015, p. 7). O ser (Seyn) é a própria história se dando no tempo-espaço. Já a historiologia não é o fundamento, não é a historicidade mesma, mas emerge dela. 
O que precisa ficar esclarecido é que a crítica de Heidegger dirigida à historiologia não indica que ela deva ser rebatida e afastada no momento de investigação filosófica. A compreensão historiológica se faz necessária para o investigador se aprofundar decididamente em sua questão de interesse, tomando parte no questionamento e nos desdobramentos da história. A questionabilidade (Fraglichkeit) advém da experiência essencial da filosofia que é estar em meio a um envio originário e dentro de uma destinação estreada pelo primeiro princípio estreado pelos gregos.

\section{CONSIDERAÇÕES FINAIS}

A partir do discorrido até aqui, vimos que Heidegger é um filósofo do outro princípio (anderer Anfang). Essa afirmação não indica que ele é um pensador superior a qualquer outro, afinal também está em meio à história como todo homem está, inserido em um contexto e lançado em questões do pensamento nas quais outros estiveram e hoje estão. Todavia, o que distingue a fenomenologia de Heidegger em relação ao pensar do primeiro princípio (erster Anfang), saber metafisico acerca do ser, é que ele abre caminho a outro modo de pensar a essência originária, não pela força, não pela vontade de representação, mas pelo acolhimento sereno do acontecimento que apropria o ente.

A importância do pensar fenomenológico de Heidegger está na sua guarda da essência da verdade como o fundamento ileso da técnica, que não se dá ao escopo do homem aponto de ser manipulada. No pensar essencial de Heidegger chamado acontecimento apropriador, não há espaço para a violência do ente contra o que o essencia (Seyn), uma vez que a verdade aqui é o que bate em retirada quando se desvela, é o ir embora da senda que nunca esteve realmente. É esse caráter de nulidade que faz do ser o singelo nada, pleno de possibilidades, o vazio repleto de significado. Mas como é possível do nada algo vir, se já na Antiguidade a máxima "do nada nada vem" é certa, segura e perpassou a história do Ocidente afirmando a sua solidez lógica? Pois bem, o pensamento heideggeriano é fenomenológico e não lógico, porque é sereno e não técnico. Assim, em Heidegger o nada tem significado e é fundante, o vazio re-vela a senda originária, porque, em hipótese alguma, podem ser identificados e representados pelo o que o homem chama de juízo. As predicações dos entes passam ao largo do verdadeiro fundamento que os lança na história.

Heidegger, na guarda do acontecimento apropriador, busca entender a história a partir do que ele chama de meditação histórica. A partir dela, a historicidade é 
essencial, incalculável, não podendo ter um valor definido, justamente porque ela se dá como abismo, um nada, que em seu não originário, pronuncia-se significativamente. Mas, no campo da técnica, temos as considerações historiológicas disciplinadas a ter o passado como fonte de representações calculantes, que podem ser datadas e definidas com segurança. Tal busca por solidez de resposta da técnica historiológica indica a insatisfação com o vazio de solo que o ser como abismo deixar acontecer.

Em síntese, podemos dizer que Heidegger é aquele que se aproxima do questionamento espantoso a respeito da verdade, que preserva o ser em seu caráter abissal, que deixa o homem sempre sem solo quando se retira em seu velamento. Ao mesmo tempo do espanto, vem a serenidade, porque sereno é aquele que acolhe a sua condição finita no mundo ao se ver lançado e deixado na existência pelo evento apropriador. No entanto, ser lançado e ser-aí no mundo reflete a possibilidade de se singularizar e se constituir, isto é, ingressar na história e dela fazer parte de modo próprio. 


\section{REFERÊNCIAS BIBLIOGRÁFICAS}

CARNEIRO LEÃO (PIZZOLANTE, Rômulo, Org.). O último Heidegger (Ereignis por

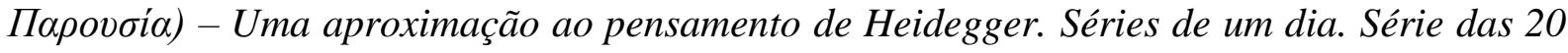
conferências de Emmanuel Carneiro Leão - 2014/2015.

HEIDEGGER, Martin. As questões fundamentais da filosofia: ( "problemas” seletos da “lógica”). São Paulo: Martins fontes, 2017.

. A questão da técnica. In: Ensaios e conferências. Petrópolis, RJ: Vozes, 2001. . Contribuições à filosofia (Do acontecimento apropriador). Rio de Janeiro: Via

Verita, 2015.

O que é isto - a filosofia? In: Os Pensadores. São Paulo: Abril Cultural, 1973. . Ser e tempo. Petrópolis, RJ: Vozes, 2012.

. Sobre o humanismo. Rio de Janeiro: Tempo Brasileiro, 1967.

INWOOD, Michael. Dicionário Heidegger. Rio de Janeiro: Jorge Zahar, 2002.

RAMOS, Daniel Rodrigues. O Ereignis em Heidegger. Teresópolis: Daimon, 2015. 